\title{
ABSTRAK \\ PENGARUH STRATEGI PEMBELAJARAN COOPERATIVE SCRIPT DAN KEMAMPUAN AKADEMIK SISWA TERHADAP KEMAMPUAN BERPIKIR KRITIS DAN PEMAHAMAN KONSEP BIOLOGI KELAS XI SMA DI KABUPATEN MALUKU TENGAH
}

\author{
Sahubauwa Laila, Aloysius Duran Corebima, Gofur Abdul \\ Program Studi Pendidikan Biologi-Pascasarjana \\ Universitas Negeri Malang, Email: lela_sahubawa@yahoo.com.
}

\begin{abstract}
Hasil analisis data menunjukkan bahwa terdapat pengaruh strategi pembelajaran dan kemampuan akademik terhadap kemampuan berpikir kritis dan pemahaman konsep siswa. Rata-rata skor terkoreksi (mean) pada strategi $C S$ dan kemampuan akademik tinggi sebesar 83,173 untuk kemampuan berpikir kritis dan 89,373 untuk pamahaman konsep. Hasil ini berbeda nyata dengan kombinasi konvensional dan kemampuan akademik rendah, konvensional dan kemampuan akademik tinggi serta kombinasi $C S$ dan kemampuan akademik rendah.
\end{abstract}

\section{Kata Kunci: Cooperative Script, Kemampuan Akademik, Kemampuan Berpikir Kritis}

The result of this research showed that there was an effect of cooperative script strategy and academic level toward student's citical thinking ability and concept achievement of biology. The best result came from student with cooperative script strategy and high level academic with corrected mean 83,171 for critical thinking ability and 89,373 for concept achievement in biology. This corrected mean was strongly different with the others (cooperative script strategy and low level academic, conventional strategy and low level academic, and also conventional strategy and low level academic).

Keywords: Cooperative Script, academic level, critical thinking

Kemampuan berpikir kritis dalam pembelajaran biologi sangat besar peranannya dalam meningkatkan proses, hasil belajar, dan bekal di masa depan. Hal ini senada dengan pernyataan dari Corebima (2007) bahwa pemberdayaan berpikir sangat penting serta strategis dalam belajar, termasuk pada proses pembelajaran Biologi. Konsep Biologi yang terdapat dalam materi pelajaran SMA begitu kompleks sehingga guru biasanya 
fokus pada pemenuhan materi dalam pembelajarannya serta kebanyakan guru belum menggunakan strategi pembelajaran yang dapat merangsang kemampuan berpikir peserta didik. Hal ini senada dengan pendapat Sudarman (2006) bahwa dalam proses pembelajaran, peserta didik kurang didorong untuk mengembangkan kemampuan berpikirnya. Proses pembelajaran di kelas lebih diarahkan kepada kemampuan anak untuk menghafal informasi. Dharma (2008) menjelaskan bahwa kemampuan pemecahan masalah dan berpikir kritis anak-anak (peserta didik) Indonesia masih sangat rendah. Rendahnya kemampuan berpikir kritis ini akan berimplikasi pada proses dan hasil belajar biologi.

Gambaran pembelajaran biologi di atas juga terjadi di beberapa sekolah di Kabupaten Maluku Tengah. Berdasarkan hasil wawancara dan survey pada beberapa SMA di Kabupaten Maluku Tengah, diketahui bahwa pembelajaran yang diterapkan masih bersifat teacher centered. Artinya dalam pembelajaran guru belum menerapkan strategi pembelajaran yang memberdayakan peserta didik. Guru juga jarang memperhatikan kemampuan akademik peserta didik yang mana di dalam satu kelas peserta didik memiliki kemampuan akademik yang berbeda-beda. Cara mengajar beberapa guru biologi lebih mengejar pada pemenuhan materi dalam pembelajaran. Pembelajaran yang dilakukan guru hanya mengacu pada tuntutan materi yang harus diselesaikan sebelum ujian akhir semester. Guru harus dapat dan cepat menyampaikan seluruh materi pembelajaran tanpa memperhatikan kemampuan pemahaman dan kemampuan berpikir kritis peserta didik. Strategi pembelajaran yang diterapkan oleh guru hanya meminta peserta didik untuk belajar, jarang mengajari peserta didik bagaimana cara belajar.

Salah satu alternatif yang digunakan untuk mengatasi permasalahan di atas adalah dengan menerapkan strategi pembelajaran yang berorientasi student centered. Cooperative script merupakan strategi pembelajaran yang mengembangkan upaya kerja sama dalam mencapai tujuan bersama, dan dapat meningkatkan hasil belajar peserta didik (Danserau, 1985). Slavin (1994) mengatakan bahwa salah satu strategi pembelajaran yang dapat meningkatkan daya ingat peserta didik adalah pembelajaran dengan strategi pembelajaran cooperative script. Kegiatan pembelajaran cooperative script peserta didik dipasangkan dengan temannya yang berperan sebagai pembicara dan pendengar. Pembicara membuat kesimpulan dari materi yang akan disampaikan 
kepada pendengar dan pendengar akan menyimak, mengoreksi, menunjukkan ide-ide pokok.

Penerapan strategi pembelajaran cooperative script diharapkan agar peserta didik berkemampuan akademik rendah lebih termotivasi untuk mengembangkan potensinya. Peserta didik berkemampuan akademik rendah dapat meningkatkan hasil belajarnya atau dapat menyamai dengan peserta didik berkemampuan akademik tinggi. Warouw (2009) menyatakan bahwa strategi pembelajaran cooperative script terbukti memperkecil jarak perolehan hasil belajar peserta didik berkemampuan akademik tinggi dan peserta didik berkemampuan akademik rendah. Hasil belajar peserta didik berkemampuan akademik tinggi, meskipun lebih tinggi, tetapi tidak menunjukkan perbedaan nyata dengan hasil belajar peserta didik berkemampuan akademik rendah.

\section{METODE PENELITIAN}

Penelitian dilaksanakan selama \pm 3 bulan (Pebruari-April) pada semester genap tahun ajaran 2013/2014. Data yang diperoleh pada saat pretes dan postes kemudian diuji statistik dengan menggunakan Anakova dengan taraf signifikan 0,05 ( $\mathrm{p}<0,05)$. Untuk mengetahui konsistensi keterlaksanaan sintaks strategi pembelajaran dilakukan uji regresi dengan menggunakan data kemampuan berpikir kritis dan pemahaman konsep antara pretes dan postes. Sebelum uji anakova terlebih dahulu dilakukan uji normalitas (Kolmogorov Svirnov) dan uji homogenitas (Levene's Test).

\section{HASIL PENELITIAN}

\section{Hasil Uji Konsistensi Keterlaksanaan Sintaks Strategi Pembelajaran}

\section{Penerapan Strategi Pembelajaran Cooperative Script}

Hasil uji konsistensi penerapan strategi pembelajaran Cooperative Script terhadap kemampuan berpikir kritis dan pemahaman konsep siswa dapat dilihat pada Gambar 1 berikut

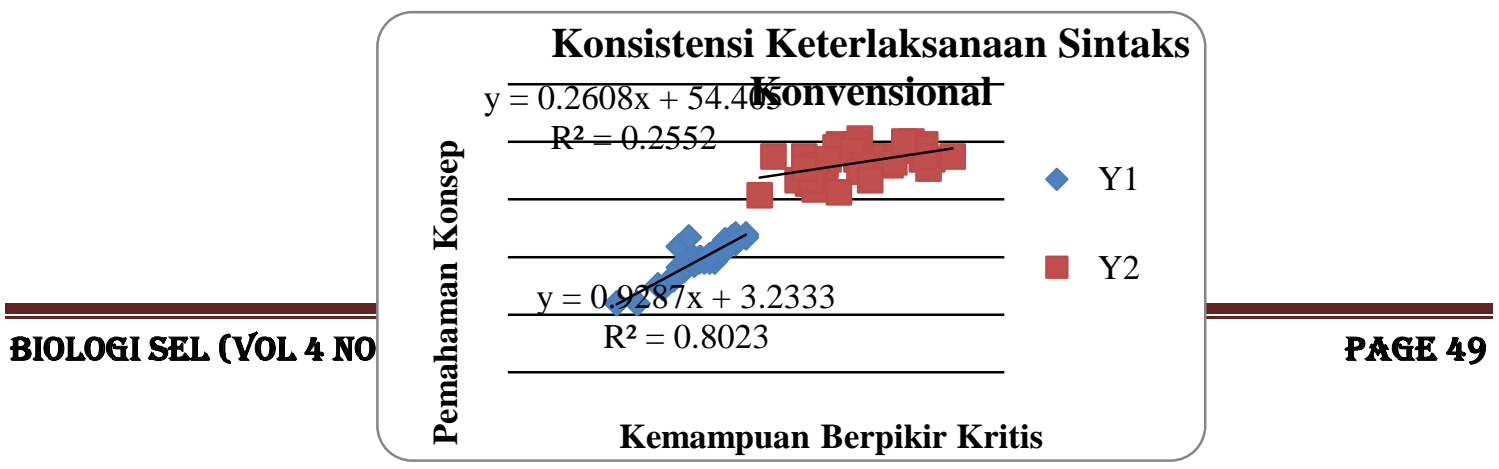


Gambar 1. Konsistensi Penerapan Strategi Pembelajaran Cooperative Script

Berdasarkan Gambar 1 di atas terlihat bahwa hasil Ypre dan Ypost sejajar. Hal ini dapat ditafsirkan bahwa penerapan strategi pembelajaran Cooperative Script telah dilakukan secara konsisten dari awal hingga akhir pembelajaran.

\section{Penerapan Strategi Pembelajaran Konvensional}

Hasil uji konsistensi penerapan strategi pembelajaran konvensional terhadap kemampuan berpikir kritis dan pemahaman konsep dapat dilihat pada Gambar 2.

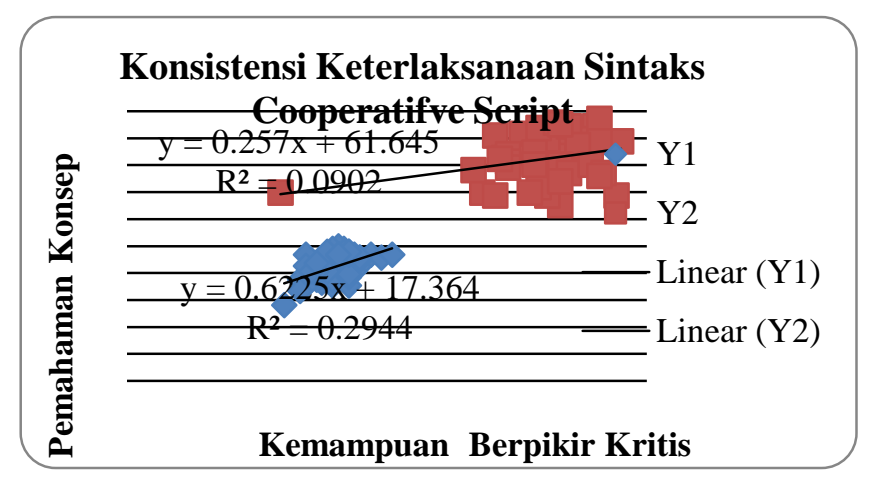

Gambar 2. Konsistensi Penerapan Strategi Pembelajaran Konvensional

Berdasarkan Gambar 2 terlihat bahwa persamaan regresi tersebut diperoleh hasil Ypre dan $\mathrm{Y}$ post sejajar. Hal ini dapat ditafsirkan bahwa penerapan strategi pembelajaran konvensional telah dilakukan secara konsisten dari awal hingga akhir pembelajaran.

\section{Kemampuan Berpikir Kritis}

Ringkasan hasil uji hipotesis pengaruh strategi pembelajaran dan kemampuan akademik terhadap kemampuan berpikir kritis siswa dengan analisis statistik anakova disajikan pada Tabel 1.

Tabel 1. Ringkasan Hasil Uji Anakova Kemampuan berpikir kritis

\begin{tabular}{lrrrrr}
\hline Source & $\begin{array}{r}\text { Type III Sum of } \\
\text { Squares }\end{array}$ & df & $\begin{array}{r}\text { Mean } \\
\text { Square }\end{array}$ & F & Sig. \\
\hline Corrected Model & $4355.299^{\mathrm{a}}$ & 4 & 1088.825 & 13.686 & .000 \\
\hline Intercept & 8712.872 & 1 & 8712.872 & 109.520 & .000 \\
\hline Y3 & 79.912 & 1 & 79.912 & 1.004 & .319 \\
\hline X1(strategi pembelajaran) & 2130.034 & 1 & 2130.034 & 26.774 & .000 \\
\hline X2(kemampuan akademik) & 1841.048 & 1 & 1841.048 & 23.142 & .000 \\
\hline X1 ${ }^{*}$ X2 & 327.731 & 1 & 327.731 & 4.120 & .046 \\
\hline Error & 6125.746 & 77 & 79.555 & & \\
\hline Total & 477062.362 & 82 & & & \\
\hline Corrected Total & 10481.045 & 81 & & & \\
\hline
\end{tabular}




\section{Pengaruh Strategi Pembelajaran}

Berdasarkan Tabel 1 Hasil uji anakova menunjukkan bahwa F hitung variabel strategi pembelajaran adalah sebesar 26, 774 dan diperoleh p-level lebih kecil dari alpha 0.05 ( $\mathrm{p}<0.05)$ dengan sig. 0,000. Hal ini berarti bahwa H0 yang menyatakan bahwa "Tidak ada pengaruh strategi pembelajaran terhadap kemampuan berpikir kritis" tidak diterima dan hipotesis penelitian yang menyatakan "Ada perbedaan pengaruh strategi pembelajaran terhadap kemampuan berpikir kritis" diterima. Jadi ada pengaruh signifikan strategi pembelajaran terhadap kemampuan berpikir kritis siswa. Data hasil penelitian menunjukkan bahwa ada perbedaan antara strategi pembelajaran konvensional dengan Cooperative Script $(C S)$. Berdasarkan hasil analisis menunjukkan bahwa rata-rata skor terkoreksi (mean) pada pembelajaran dengan strategi konvensional sebesar 70,170 dan strategi pembelajaran $C S$ sebesar 80,444. Oleh karena itu, dikatakan bahwa rata-rata skor terkoreksi pada pembelajaran dengan strategi $C S$ sebesar $14,64 \%$ lebih tinggi dibandingkan dengan pembelajaran dengan strategi konvensional.

\section{Pengaruh Kemampuan Akademik}

Data hasil penelitian menunjukkan bahwa ada perbedaan antara kemampuan akademik tinggi dengan kemampuan akademik rendah. Berdasarkan hasil analisis menunjukkan bahwa rata-rata skor terkoreksi pada kemampuan akademik tinggi sebesar 80,051 sedangkan pada kemampuan akademik rendah sebesar 70,562. Ini menunjukkan bahwa rata-rata skor terkoreksi pada kemampuan akademik tinggi 13,45\% lebih tinggi dibandingkan dengan kemampuan akademik rendah.

\section{Pengaruh Interaksi Strategi Pembelajaran dan Kemampuan Akademik}

Berdasarkan Tabel 1 hasil uji anakova interaksi strategi pembelajaran dan kemampuan akademik diperoleh nilai $\mathrm{F}$ hitung sebesar 4,120 dengan p-level lebih kecil dari alpha 0,05 ( $\mathrm{p}>0,05)$ dengan sig. 0,046. Hal ini berarti hipotesis penelitian yang menyatakan "ada pengaruh interaksi strategi pembelajaran dan kemampuan akademik terhadap kemampuan berpikir kritis" diterima. Hal Ini dapat terlihat pada hasil ringkasan uji lanjut pada Tabel 2.

Tabel 2. Ringkasan Hasil Uji Lanjut Pengaruh Interaksi Perlakuan terhadap Kemampuan berpikir kritis 


\begin{tabular}{llrrrrr}
\hline Strategi & $\begin{array}{l}\text { Kemampuan } \\
\text { Akademik }\end{array}$ & \multicolumn{1}{l}{ Xkritis } & \multicolumn{1}{l}{ Ykritis } & \multicolumn{1}{l}{ Selisih } & \multicolumn{1}{l}{ Kritiscor } & Notasi LSD \\
\hline Konv & Rendah & 39,898 & 63,368 & 23,470 & 63,411 & a \\
\hline Konv & Tinggi & 39,882 & 77,675 & 37,793 & 76,930 & b \\
\hline CS & Rendah & 38,222 & 77,222 & 39,000 & 77,714 & \multicolumn{2}{c}{$\mathrm{b}$} \\
\hline CS & Tinggi & 40,675 & 82,975 & 42,300 & 83,173 & c \\
\hline
\end{tabular}

Berdasarkan tabel 2 terlihat bahwa rata-rata skor kombinasi antara $C S$ dengan kemampuan akademik tinggi memiliki rata-rata skor tertinggi dan kombinasi antara konvensional dengan kemampuan akademik rendah memiliki rata-rata skor terendah. Hasil uji lanjut dengan Least Significant Difference (LSD) menunjukkan bahwa ada perbedaan yang signifikan (nyata) antara kombinasi $C S$ dan kemampuan akademik tinggi dengan kombinasi konvensional dan kemampuan akademik tinggi. Perbedaan tersebut yakni kombinasi $C S$ dan kemampuan akademik tinggi lebih tinggi 8,11\% jika dibandingkan dengan kombinasi konvensional dan kemampuan akademik tinggi. Ratarata skor kombinasi strategi konvensional dan kemampuan akademik tinggi $(76,930)$ tidak berbeda nyata dengan kombinasi startegi $C S$ dan kemampuan akademik rendah (77,714).

\section{Pemahaman Konsep}

Ringkasan hasil uji hipotesis pengaruh strategi pembelajaran dan kemampuan akademik terhadap pemahaman konsep siswa dengan menggunakan analisis statistik anakova terlihat pada Tabel 3 berikut ini.

Tabel 3. Ringkasan Hasil Uji Hipotesis Anakova Pemahaman Konsep

\begin{tabular}{lrrrrr}
\hline Source & $\begin{array}{r}\text { Type III Sum of } \\
\text { Squares }\end{array}$ & df & Mean Square & F & Sig. \\
\hline Corrected Model & $4337.156^{\mathrm{a}}$ & 4 & 1084.289 & 42.532 & .000 \\
\hline Intercept & 6782.813 & 1 & 6782.813 & 266.061 & .000 \\
\hline Y1 & 27.989 & 1 & 27.989 & 1.098 & .298 \\
\hline $\begin{array}{l}\text { X1(Strategi } \\
\text { Pembelajaran) }\end{array}$ & 1612.725 & 1 & 1612.725 & 63.260 & .000 \\
\hline $\begin{array}{l}\text { X2(kemampuan } \\
\text { akademik) }\end{array}$ & 2070.149 & 1 & 2070.149 & 81.203 & .000 \\
\hline X1 ${ }^{*}$ X2 & 332.927 & 1 & 332.927 & 13.059 & .001 \\
\hline Error & 1962.996 & 77 & 25.493 & & \\
\hline Total & 500469.442 & 82 & & & \\
\hline Corrected Total & 6300.151 & 81 & & & \\
\hline
\end{tabular}

Berdasarkan Tabel 3 hasil uji anakova pada variabel strategi pembelajaran diperoleh nilai $\mathrm{F}$ hitung sebesar 63,260 dan p-level lebih kecil dari alpha 0.05 ( $\mathrm{p}<0.05)$ dengan sig. 0,000. Hal ini berarti bahwa hipotesis penelitian yang menyatakan "ada pengaruh strategi pembelajaran terhadap pemahaman konsep" diterima. Jadi, ada pengaruh signifikan strategi pembelajaran terhadap pemahaman konsep siswa. Data hasil penelitian menunjukkan bahwa ada perbedaan antara strategi pembelajaran konvensional dengan $C S$. Berdasarkan hasil analisis menunjukkan bahwa rata-rata skor 
terkoreksi (mean) pada pembelajaran dengan strategi $C S$ sebesar 82,130 sedangkan pada pembelajaran dengan konvensional sebesar 72,906. Hal ini menunjukkan bahwa ratarata skor terkoreksi (mean) pada pembelajaran dengan strategi $C S 12,65 \%$ lebih tinggi dibandingkan dengan pembelajaran dengan strategi konvensional.

\section{Pengaruh Kemampuan Akademik}

Data hasil penelitian menunjukkan bahwa ada perbedaan antara kemampuan akademik tinggi dengan kemampuan akademik rendah. Berdasarkan hasil analisis menunjukkan bahwa rata-rata skor terkoreksi pada kemampuan akademik tinggi sebesar 82,720 sedangkan pada kemampuan akademik rendah sebesar 72,315. Ini menunjukkan bahwa rata-rata skor terkoreksi pada kemampuan akademik rendah 14,39\% lebih tinggi dibandingkan dengan kemampuan akademik tinggi.

\section{Pengaruh Interaksi Strategi Pembelajaran dan Kemampuan Akademik}

Berdasarkan Tabel 3 hasil uji anakova pada variabel interaksi strategi pembelajaran dan kemampuan akademik diperoleh nilai $\mathrm{F}$ hitung sebesar 4,120 dan plevel lebih kecil dari alpha $0,05(\mathrm{p}<0,05)$ dengan sig. 0,001. Hal ini berarti bahwa hipotesis penelitian yang menyatakan "ada pengaruh interaksi strategi pembelajaran dan kemampuan akademik terhadap pemahaman konsep" diterima. Jadi, ada pengaruh signifikan interaksi strategi pembelajaran dan kemampuan akademik terhadap pemahaman konsep. Ringkasan hasil uji lanjut pengaruh interaksi perlakuan terhadap pemahaman konsep terlihat pada tabel 4 berikut.

Tabel 4. Ringkasan Hasil Uji Lanjut Pengaruh Interaksi Perlakuan terhadap Pemahaman Konsep

\begin{tabular}{llccccc}
\hline \multicolumn{1}{c}{ Strategi } & $\begin{array}{c}\text { Kemampuan } \\
\text { Akademik }\end{array}$ & $\mathrm{XHb}$ & $\mathrm{YkHB}$ & Selisih & HBcor & $\begin{array}{c}\text { Notasi } \\
\text { LSD }\end{array}$ \\
\hline Konvensional & Rendah & 40.053 & 69.637 & 29.584 & 69.745 & $\mathrm{a}$ \\
\hline Konvensional & Tinggi & 38.959 & 75.835 & 36.876 & 76.067 & $\mathrm{~b}$ \\
\hline$C S$ & Rendah & 44.645 & 75.298 & 30.653 & 74.886 & $\mathrm{~b}$ \\
\hline$C S$ & Tinggi & 40.229 & 89.285 & 49.056 & 89.373 & $\mathrm{c}$ \\
\hline
\end{tabular}

Berdasarkan Tabel 4 terlihat bahwa rata-rata skor kombinasi antara CS dengan kemampuan akademik tinggi memiliki rata-rata skor tertinggi sebesar 89,373 dan kombinasi antara konvensional dengan kemampuan akademik rendah memiliki rata-rata skor terendah sebesar 69,745. Hasil uji lanjut dengan Least Significant Difference (LSD) menunjukkan bahwa ada perbedaan yang signifikan (nyata) antara kombinasi konvensional dan kemampuan akademik rendah dengan kombinasi $C S$ dan kemampuan 
akademik rendah, kombinasi $C S$ dan kemampuan akademik tinggi dengan kombinasi konvensional dan kemampuan akademik tinggi. Tidak terdapat perbedaan signifikan antara kombinasi strategi $C S$ dan kemampuan akademik rendah dengan kombinasi strategi konvensional dan kemampuan akademik tinggi.

\section{PEMBAHASAN}

Hasil uji anakova menunjukkan bahwa ada pengaruh strategi pembelajaran Cooperative Script terhadap kemampuan berpikir kritis siswa. Strategi pembelajaran cooperative script yang diterapkan pada kelas eksperimen menghasilkan rata-rata peningkatan yang lebih tinggi dibandingkan dengan pembelajaran konvensional. Pengaruh strategi pembelajaran cooperative script yang lebih baik dari strategi pembelajaran konvensional disebabkan karena strategi pembelajaran cooperative script memiliki keunggulan-keunggulan.

Strategi pembelajaran cooperative script merupakan strategi pembelajaran kooperatif yang menitikberatkan pembelajaran pada membaca dan membuat ringkasan hasil bacaan. Siswa bekerja secara berkelompok yang terdiri dari 2 orang, dimana masing-masing siswa akan membuat ringkasan. Selanjutnya, siswa A akan membacakan hasil membuat ringkasan kemudian dikoreksi oleh siswa B selaku pendengar dengan menunjukkan ide-ide pokok yang belum tercakup di dalam hasil meringkas siswa A. Setelah mengoreksi hasil meringkas siswa A, maka kedua siswa saling bertukar peran, sehingga peran sebagai pembicara dan pendengar akan dilakukan oleh keduanya.

Spurlin dalam Slavin (1994) menjelaskan bahwa dalam pembelajaran dengan strategi pembelajaran cooperative script, siswa juga mendapatkan kesempatan mempelajari bagian lain dari materi yang tidak dipelajarinya. Membaca dan membuat ringkasan yang berupa ide-ide pokok dari materi yang telah dibaca, siswa dapat menemukan sebuah atau beberapa pertanyaan yang berhubungan dengan materi yang telah dibaca. Pertanyaan-pertanyaan tersebut dapat membantu siswa untuk lebih melatih kemampuan berpikirnya.

Temuan dalam penelitian ini didukung oleh penelitian sebelumnya tentang kelebihan strategi pembelajaran cooperative script. Penelitian yang dilakukan oleh Hadi (2007) menunjukkan bahwa strategi pembelajaran cooperative script sangat membantu peserta didik dalam belajar di kelas. Peserta didik menjadi lebih termotivasi dalam belajar sehingga memunculkan suatu ide-ide dan pendapat baru yang berhubungan 
dengan materi pelajaran, sehingga mengindikasikan bahwa strategi pembelajaran cooperative script mampu memacu peserta didik untuk berpikir kritis. Hal ini terlihat dari hasil uji lanjut strategi pembelajaran cooperative script berpengaruh 22,16\% lebih baik dari strategi pembelajaran konvensional terhadap kemampuan berpikir kritis siswa.

Hasil penelitian Tumbel (2011) juga menunjukkan bahwa terdapat pengaruh strategi pembelajaran cooperative script terhadap kemampuan berpikir siswa. Rata-rata skor kemampuan berpikir siswa yang belajar dengan strategi cooperative script lebih tinggi dibandingkan dengan rata-rata skor kemampuan berpikir siswa yang belajar dengan strategi pembelajaran konvensional. Tingginya skor kemampuan berpikir siswa berimplikasi dari penerapan strategi pembelajaran cooperative script yang merupakan pembelajaran kooperatif struktural yang menitikberatkan pembelajaran pada membaca dan membuat ringkasan hasil bacaan.

Salah satu faktor yang diduga mempengaruhi pemahaman konsep siswa selain kemampuan berpikir kritis adalah minat siswa. Siswa yang memiliki minat yang besar terhadap pembelajaran biologi sehingga siswa memperhatikan dan mengikuti setiap kegiatan belajar biologi dengan rasa senang. Slameto (2010) mengungkapkan bahwa minat besar pengaruhnya terhadap belajar, karena bila bahan pelajaran yang dipelajari tidak sesuai dengan minat siswa, siswa tidak akan belajar dengan sebaik-baiknya, adanya minat terhadap pelajaran membuat siswa menjadi memiliki motif untuk berpikir dan memusatkan perhatian, merencanakan, dan melaksanakan kegiatan yang menunjang belajarnya sehingga kemampuan berpikir kritis siswa meningkat yang diikuti dengan peningkatan pemahaman konsep siswa.

Hasil penelitian ini sejalan dengan penelitian sebelumnya yang dilakukan oleh Surachman (2010). Hasil penelitiannya menunjukkan adanya hubungan antara kemampuan berpikir kritis dan pemahaman konsep dalam Pembelajaran Berbasis Proyek (PBP). PBP sama halnya dengan strategi cooperative script merupakan strategi pembelajaran yang memberdayakan kemampuan berpikir kritis siswa.

Yuanita (2010) juga menjelaskan bahwa ada hubungan yang signifikan antara kemampuan berpikir kritis dan hasil belajar kognitif pada pembelajaran biologi. Siswa yang memiliki kemampuan berpikir kritis akan mudah menguasai, memahami, dan 
mengingat materi pembelajaran dengan baik. Secara ideal, strategi pembelajaran yang dapat memberdayakan kemampuan berpikir kritis akan mempengaruhi hasil belajar kognitif dan sebaliknya hasil belajar mempengaruhi kemampuan berpikir kritis siswa. Hasil belajar juga akan mempengaruhi sikap siswa dan sebaliknya (Latif 2010).

Pemahaman konsep siswa didapat dengan mengkonstruk pengetahuan yang dimiliki siswa sendiri. Siswa mengkonstruk pengetahuan tersebut melalui suatu proses yang disebut berpikir, termasuk berpikir kritis. Kemampuan seseorang dalam berpikir akan mempengaruhi pemahaman seseorang. Gunter (1990) menyatakan bahwa terjadi keterkaitan yang erat antara mengingat dan memahami, dan antara memahami dan berpikir. Besarnya peran berpikir kritis untuk membangun pemahaman konsep merupakan implikasi dari sintaks strategi cooperative script.

\section{KESIMPULAN}

Berdasarkan hasil analisis data dan pembahasan terhadap hasil penelitian, dapat disimpulkan bahwa: 1) ada pengaruh strategi pembelajaran Cooperative Script terhadap kemampuan berpikir kritis siswa dan pemahaman konsep. Rata-rata skor terkoreksi kemampuan berpikir kritis siswa 14,64\% dan pemahaman konsep siswa 12, 65\% yang belajar dengan strategi pembelajaran Cooperative Script lebih tinggi dari siswa yang belajar dengan strategi pembelajaran konvensional; 2) ada pengaruh kemampuan akademik terhadap kemampuan berpikir kritis dan pemahaman konsep siswa. Rata-rata skor terkoreksi kemampuan berpikir kritis siswa 13,45\% dan pemahaman konsep siswa 14,39\% yang berkemampuan akademik tinggi lebih tinggi dibandingkan dengan siswa berkemampuan akademik rendah; dan 3) ada pengaruh interaksi strategi pembelajaran Cooperative Script dan kemampuan akademik terhadap kemampuan berpikir kritis dan pemahaman konsep siswa. Rata-rata skor terkoreksi interaksi kemampuan berpikir kritis $31,16 \%$ dan pemahaman konsep $28,14 \%$ siswa yang strategi pembelajaran Cooperative Script dan kemampuan akademik siswa

\section{SARAN}

1. Bagi guru dan peneliti yang berminat terhadap strategi pembelajaran cooperative script hendaknya memperhatikan temuan penelitian ini bahwa strategi pembelajaran cooperative script efektif untuk memberdayakan kemampuan berpikir kritis baik pada materi sistem pernapasan maupun materi sistem ekskresi, 
selanjutnya strategi pembelajaran cooperative script juga efektif untuk memberdayakan pemahaman konsep.

2. Bagi peneliti dan guru yang berminat dalam upaya pemberdayaan kemampuan berpikir kritis dan pemahaman konsep pada berbagai tingkat kemampuan akademik hendaknya memperhatikan temuan penelitian ini bahwa kemampuan akademik tinggi memiliki kemampuan berpikir kritis dan pemahaman konsep yang lebih baik. Strategi cooperative script dapat meningkatkan kemampuan berpikir kritis dan pemahaman konsep siswa berkemampuan akademik rendah.

3. Bagi peneliti lain yang berminat menggunakan cooperative script, dan sebagai strategi pembelajaran yang belum banyak diteliti dan diimplementasikan dalam pembelajaran di kelas khususnya di Indonesia, perlu ditindaklanjuti pada materi Biologi.

\section{DAFTAR PUSTAKA}

Corebima, A. D. 2007. Learning Strategi to Empower Students Thinking Skill. (Online),http://www.recsam.edu.my/cosmed/cosmed07/AbstractsFullPapers20 07/SCIENCE\%5CS042A.pdf. diakses tanggal 5 Desember 2013.

Dansereau, D. F (1985). Learning Strategy Research. In J.W. Segal. S. F. Chipman, \& R. Glaser (Eds), Thinking and Learning Skills: vol. 1, Relating Instruction to Research. Hillsdale. NJ: Erlbaum.

Dharma, S. 2008. Strategi Pembelajaran dan Pemilihannya. Jakarta: Departeme Pendidikan Nasional.

Degeng, N. S. 1989. Ilmu Pengajaran: Taksonomi Variabel. Jakarta: Dirjen Pendidikan Tinggi.

Gunter, A. L., et al. 1990. Instruction a Model Approach. London: Allyn and Bacon.

Hadi S. 2007. Pengaruh Strategi Cooperative Script terhadap Ketrampilan Berpikir Kritis, Kemampuan Metakognitif, dan Kemampuan Kognitif Siswa SMA Laboratorium UM. Tesis tidak diterbitkan. Malang: PPS Universitas Negeri Malang.

Hart, D. 1994. Authentic Assesment A Handbook for Educators. California, New York: Addison-Wesley Publishing Company.

Latif, M. A. 2010. Pengaruh Pembelajaran Cooperative Script Dipadu dengan Pola Pemberdayaan Berpikir Melalui Pertanyaan (PBMP) terhadap Kemampuan Berpikir Kritis dan Hasil Belajar Biologi Siswa Kelas X MAN 3 Malang. Skripsi tidak diterbitkan. Malang: Jurusan Biologi Universitas Negeri Malang. 